\title{
Progress to Date and Future Perspective of Ocean Research
}

\author{
Raquel Somavilla* \\ Instituto Español de Oceanografía, Spain
}

Submission: February 24, 2018; Published: May 11, 2018

*Corresponding author: Somavilla R, Instituto Español de Oceanografía. C.O. de Santander, Spain, Email: rsomavillacabrillo@gmail.com

Abstract

Most recently signed economic, political, and social agreements such as the Paris Agreement, the 2030 Agenda for Sustainable Development, or the FAO's Blue Growth Initiative have as common objective the strengthening of the global response to the threat of climate change holding the increase in the global average temperature well below $2{ }^{\circ} \mathrm{C}$ above pre-industrial levels. Aside of the implementation of ambitious plans on adaptation and mitigation, our ability to contain climate change within safe limits depends largely on the evolution of the ocean circulation and state. The increased awareness of the rapid degradation of the ocean and its importance to the future of humanity is the result of decades of ocean research that has finally been embodied by the proclamation of a Decade of Ocean Science for Sustainable Development (2021-2030) by the United Nations General Assembly. In the framework of this program, there is an extraordinary opportunity to connect ocean sciences more directly with policy-makers, business, and civil society around a program of joint research and technological innovation [1].

\section{Present Situation}

Decades of marine research have provided clear evidence of the crucial role of the ocean in the past, present and future climate and in the origin and maintenance of life. Now, we know that the oceans cover more than seventy percent of the Earth surface and due to its large volume and its thermal inertia -about 4000 times greater than that of the air- the ocean accumulates 93\% of the energy in the Earth Climate System, being the main driver of climate regulation and acting as a heat buffer for climate warming [2]. Besides, the global ocean not only absorbs, stores, and redistributes vast amounts of heat but also of carbon. The ocean contains 50 times more carbon than the atmosphere and it is actively absorbing about $30 \%$ of the emitted anthropogenic carbon dioxide (CANT) [3]. 50\% of the oxygen in Earth's atmosphere is produced in the upper layers of the ocean by phytoplankton [4]. The regulation of atmospheric and marine carbon dioxide $\left(\mathrm{CO}_{2}\right)$ concentrations and the provision of oxygen are just some of the services that marine ecosystems and marine biodiversity provide for human well-being. Obviously, they also provide fish and shellfish, representing the primary source of animal protein in the diets of approximately 1 billion people (mostly in developing countries) [5].

However, in the last decades an important question has arisen influencing irremediably the scientific progress: Is the climate on Earth changing and is that change induced by the human being? Due to its crucial role in the Earth's climate, contributing to answer this question has also determined oceanographic research. As greenhouse gases increase the Earth radiative imbalance (the energy that we receive from the sun exceeds the energy that leaves the atmosphere back to the space), the oceans sequester up to $93 \%$ of the extra heat in the climate system [1], and as a result, the ocean is warming $[6,7]$. The drastic surge in anthropogenic $\mathrm{CO}_{2}$ emissions since the industrialisation not only results in ocean warming but is also the cause of ocean acidification (progressive increase in ocean inorganic carbon concentrations and decreased water $\mathrm{pH}$ and calcium carbonate saturation) and a significant decrease in the dissolved oxygen content [3]. In parallel with these changes, the human population has been introducing an increasing level of nutrients into coastal waters, leading to problems of eutrophication and severe oxygen deficits in coastal waters [8]. In $2011,28.8 \%$ of the fish stocks were overexploited; $61.3 \%$ fully exploited; and $9.9 \%$ underexploited [5]. Next, this review briefly outlines a range of critical consequences of ocean warming, acidification and deoxygenation and future challenges of marine research.

\section{Ocean Warming}

Over the period from 1971 to 2010, the ocean warmed at average rates of $0.1{ }^{\circ} \mathrm{C} /$ decade in the upper 75 metres $(\mathrm{m})$ of the water column and $0.015{ }^{\circ} \mathrm{C} /$ decade in the first $2000 \mathrm{~m}$ [6]. Although these temperature increases may seem small, they should be seen in relation to the large body of water that has been heated. If the same amount of heat that had been buried in the upper $2000 \mathrm{~m}$ of the ocean would had been accumulated in the atmosphere, the surface of the Earth would have warmed up to $36^{\circ} \mathrm{C}$ instead of $1^{\circ} \mathrm{C}$ for the past 40 years. 
Ocean surface warming is commonly associated with a more stratified, less productive, and less oxygenated ocean. Such an assertion is mainly based on consistent projections of increased near surface stratification and shallower mixed layers under global warming scenarios $[9,10]$. However, as shown in [11] this statement cannot be considered globally applicable and outcomes may differ by region. Ocean warming is causing fish, birds, sea turtles, and other species to change their behavior and habitat. All organisms specialize in a limited range of ambient temperatures for optimal performance. An organism under climatic conditions exceeding these limits can see affected its immune system, growth, body size, and behavior [12]. Species are moving into deeper waters and towards higher and cooler latitudes at a speed that is up to five times faster than the displacements observed by species on land. In the composition of the fisheries' catches, a shift of 30 to $130 \mathrm{~km}$ towards the poles of the species captured in North Atlantic, Antarctic and Arctic waters and $3.5 \mathrm{~m} /$ decade into deeper waters has been observed $[13,14]$.

The thermal expansion of the ocean and the melting of glaciers are the main factors responsible for the rise in mean sea level in the 20th century. Sea level rise introduces saline water into the deltas and estuaries, where aquaculture is commonly carried out, forcing the facilities to move upstream. The spread of infectious diseases in a warmer ocean also represents a major threat to aquaculture, as observed for example in oyster and abalone aquaculture [15].

\section{Ocean Acidification}

Ocean acidification represents one of the major drivers of ocean physical and biological changes. The $\mathrm{pH}$ value of ocean surface water has decreased by $0.1 \mathrm{pH}$ units since the pre-industrial period [16]. Excess of $\mathrm{CO}_{2}$ in seawater reduces the availability of carbonate ions which are necessary for marine calcifying organisms with shells and calcareous skeletons consisting of aragonite $\left(\mathrm{CaCO}_{3}\right)$, such as corals, molluscs, echinoderms and crustaceans [17]. This leads to reductions in survival, calcification, growth, development and abundance for these marine organisms with implications for aquaculture. Regarding fisheries, it is rather the interactive effects of $\mathrm{pH}$ decrease with other stressors, such as warming or eutrophication, that may potentially lead to long-term changes in species composition [18].

\section{Deoxygenation}

The decrease in the concentration of oxygen in the ocean is the result of the decrease in the solubility of oxygen due to the heating of the ocean, the decrease in its ventilation [4], and changes in respiration rates. Ocean deoxygenation is causing the expansion and shoaling of oxygen minimum zones (OMZs), which are expected to cause a decrease in demersal fish diversity and alteration of trophic networks [18]. Hypoxia intolerant and high oxygen-demand species are expected to undergo habitat compression, making them more susceptible to overfishing. It is likely that demersal fisheries will be adversely affected by the expansion of OMZs [19]. OMZs are found in the subtropical and tropical zones of the Atlantic, Pacific and Indian Oceans.

\section{Future perspective of Ocean Research}

The most prominent advances in physical oceanography in the last 20 years have been summarized in the recognition that ocean variability at meso- and submesoscales and oceantopography interactions are crucial in shaping the elementary features of ocean circulation [20]. Satellite measurements and mesoscale eddy-permitting global general circulation models have revealed the ocean -far from behaving according to linear approximations- to be intrinsically turbulent [21]. This recognition that the mean state of the ocean is largely determined by turbulent aspects of the flow and interactions with topography has significantly change the way the oceanographic community approaches the study of ocean circulation. In the WOCE-era, it was expected to obtain a meaningful estimate of the time-mean ocean circulation through standard oceanographic sections and using quasi-steady-state inverse estimation techniques. This approach has been replaced by observation efforts including a wide range of measurements (oceanographic sections, Argo buoys, gliders, drift buoys, autonomous profilers, etc.) and models that assimilate such data to estimate the evolving state of a turbulent ocean.

The situation for biogeochemistry and marine ecology is substantially different. Currently, the factors that force marine ecosystems and biogeochemical cycles are not fully understood, nor the response to these stressors or the synergy between them [22]. Fisheries research with the objective of knowing the state of the stocks of fish, molluscs and crustaceans is possibly even more deficient of a deep knowledge of how the abiotic factors affect the species and the fishing activity. Besides, a transition in the way of approaching the study of the mean state of the ocean has not yet taken place for marine ecology and biogeochemical studies. The need of samples for analytical determinations hinders this progress. However, the information that can be obtained from optical sensors has not been exploited to its full potential, and the use of state-of-the-art autonomous ocean technology to study marine ecosystems and biogeochemical cycles is the area of biogeochemical oceanography where major advances are to be expected in the coming decades. Concerning physical oceanography, the role of the circulation in the coupled climate and the dissipative processes for having received less attention until recently due to the difficulties in observing and modelling flows on the smallest length scales and shortest time scales of the circulation are the areas where major advances are to be expected in the coming decades $[20,21]$.

Apart from the expected advances in each of these areas, the proclamation of a Decade of Ocean Science for Sustainable Development (2021-2030) by the United Nations General 
Assembly gives an extraordinary opportunity to the scientific community for multilateral cooperation with policy-makers and civil society with the capacity to transform the field of Ocean Sciences [1].

\section{References}

1. Visbeck (2018) Ocean science research is key for a sustainable future. Nat Commun 9(1): 690.

2. Alexander (2013) IPCC Fifth Assessment Report Climate Change 2013: The Physical Science Basis.

3. Keeling, Körtzinger A, Gruber N (2010) Ocean deoxygenation in a warming world. Ann Rev Mar Sci 2: 199-229.

4. Le Quéré, Moriarty R, Andrew RM, Canadell JG, Sitch S, et al. (2015) Global Carbon budget. Earth System Science Data 7: 349-396.

5. FAO (2014) The State of World of Fisheries and Aquaculture 2014: Opportunities and Challenges.

6. Balmaseda, Kevin E Trenberth, Erland Källén (2013) Distinctive climate signals in reanalysis of global ocean heat content, Geophysical Research Letters 40(9): 1754-1759.

7. Roemmich, John Church, John Gilson, Didier Monselesan, Philip Sutton, et al. (2015) Unabated planetary warming and its ocean structure since 2006. Nature Climate Change 5(3): 240-245.

8. Diaz, Rosenberg R (2008) Spreading dead zones and consequences for marine ecosystems. Science 321(5891): 926-929.

9. Gruber (2011) Warming up, turning sour, losing breath: ocean biogeochemistry under global change. Philos Trans A Math Phys Eng Sci 369(1943): 1980-1996.

10. Capotondi, Michael A Alexander, Nicholas A Bond, Enrique N Curchitser, James D Scott (2012) Enhanced upper ocean stratification with climate change in the CMIP3 models. J Geophys Res Oceans 117(C4).

11.Somavilla, González-Pola C, Fernández-Diaz J (2017) The warmer the ocean surface, the shallower the mixed layer. How much of this is true? J Geophys Res Oceans 122(9): 7698-7716.

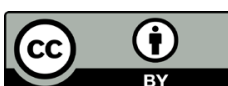

his work is licensed under Creative Commons Attribution 4.0 Licens

DOI: $10.19080 /$ OFOAJ.2018.07.555712
12.Pörtner et al. (2014) Chapter 6, in: Climate Change 2014: Impacts, Adaptation, and Vulnerability, Fifth Assessment Report of the Intergovernmental Panel on Climate Change.

13.Gattuso, Magnan A, Billé R, Cheung WWL, Howes EL, et al. (2015) Contrasting futures for ocean and society from different anthropogenic CO2 emissions scenarios. Science 349: 6243.

14.Beaugrand, Martin Edwards, Louis Legendre (2010) Marine biodiversity, ecosystem functioning, and carbon cycles. Procee of the Natio Acad of Sciences 107(22): 10120-10124.

15. Burge, Mark Eakin C, Carolyn S Friedman, Brett Froelich, et al. (2014) Climate change influences on marine infectious diseases: Implications for management and society. Annual Review of Marine Science 6: 249277.

16. Hoegh-Guldberg, John F Bruno (2010) The impact of climate change on the world's marine ecosystems. Science 328(5985): 1523-1528.

17.Fabry, Brad A Seibel, Richard A Feely, James C Orr (2008) Impacts of ocean acidification on marine fauna and ecosystem processes. ICES Journal of Marine Science 65(3): 414-432.

18. Wittmann, Pörtner (2013) Sensitivities of extant animal taxa to ocean acidification. Nature Climate Change 3: 995-1001.

19. Gallo ND, Levin LA (2016) Fish Ecology and Evolution in the World's Oxygen Minimum Zones and Implications of Ocean Deoxygenation. Adv Mar Biol 74: 117-198.

20.Garabato $N$ (2012) A perspective on the future of physical oceanography. Philos Trans A Math Phys Eng Sci 370: 5480-5511.

21.Shuckburgh E (2012) Oceanographers' contribution to climate modelling and prediction: progress to date and a future perspective. Philos Trans A Math Phys Eng Sci 370(1980): 5656-5681.

22. Rees AP (2012) Pressures on the marine environment and the changing climate of ocean biogeochemistry. Philos Trans A Math Phys Eng Sci 370(1980): 5613-5635.

\section{Your next submission with Juniper Publishers} will reach you the below assets

- Quality Editorial service

- Swift Peer Review

- Reprints availability

- E-prints Service

- Manuscript Podcast for convenient understanding

- Global attainment for your research

- Manuscript accessibility in different formats

( Pdf, E-pub, Full Text, Audio)

- Unceasing customer service

Track the below URL for one-step submission https://juniperpublishers.com/online-submission.php 